\title{
PENGARUH TINGKAT KEMATANGAN DAN KONSENTRASI EKSTRAK KULIT PISANG AGUNG SEMERU TERHADAP Staphylococcus aureus
}

\section{EFFECT THE LEVEL OF MATURNITY AND CONCENTRATION OF "AGUNG SEMERU” BANANA PEEL EXTRACT ON Staphylococcus aureus}

\author{
Siti Nur Kholifah ${ }^{1}$, Dwi Nur Rikhma Sari ${ }^{2}$, Septarini Dian Anitasari ${ }^{3}$ \\ Pendidikan Biologi FP. MIPA IKIP PGRI Jember \\ Email:dnrs129_dinnurrisa@yahoo.com
}

\begin{abstract}
ABSTRAK
Staphylococcus aureus merupakan salah satu bakteri Gram positif yang bisa menular pada manusia. Salah satu upaya untuk mengatasi penyakit menular yang disebabkannya yaitu dengan menggunakan berbagai jenis antibiotik. Penelitian ini bertujuan untuk mengetahui aktivitas ekstrak kulit pisang agung semeru sebagai agen antimikroba terhadap Staphylococcus aureus. Desain penelitian ini menggunakan True Experimental dengan Postest-Only Control Design yang dilakukan dengan metode Difusi in vitro. Hasil uji menunjukkan aktivitas antibakteri metode penyebaran terbaik DHP pada konsentrasi ekstrak kulit pisang mentah $100 \mathrm{mg} / \mathrm{mL}$ adalah 21,66 $\pm 0,31565$ mm. Hasil uji Kruskal-Wallis menunjukkan perbedaan yang signifikan dalam diameter penghambatan pertumbuhan antara kelompok perlakuan. Hasil uji post LSD dan Duncan post hoc menunjukkan konsentrasi ekstrak $3,1 \mathrm{mg} / \mathrm{mL} ; 50 \mathrm{mg} / \mathrm{mL}$ dan 100 $\mathrm{mg} / \mathrm{mL}$ menunjukkan perbedaan yang signifikan dengan konsentrasi lainnya.
\end{abstract}

Kata Kunci : Staphylococcus aureus, Kulit Pisang, Pisang Agung Semeru

\begin{abstract}
Staphylococcus aureus was one of the gram positive bacteria which can be infection in humans. One of the efforts to address infectious disease caused by it is by using different types of antibiotics. This research aimed to know the extract activities of Agung Semeru banana peels as antimicrobial agent against Staphylococcus aureus. This research design used True Experimental with PostestOnly Control Design which were done by in vitro Diffusion methods. The test results demonstrate the antibacterial activity of DHP best diffusion method at a concentration of unripe banana skin extract $100 \mathrm{mg} / \mathrm{mL}$ is $21.66 \pm 31565 \mathrm{~mm}$.KruskalWallis test results showed significant differences in growth inhibition diameter between the treatment groups. Result of post hoc LSD and Duncan test showed concentration of extract $3.1 \mathrm{mg} / \mathrm{mL} ; 50 \mathrm{mg} / \mathrm{mL}$ and $100 \mathrm{mg} / \mathrm{mL}$ showed significant differences with other concentrations
\end{abstract}

Keywords : Staphylococcus aureus, Banana Peel, Agung Semeru Banana 


\section{PENDAHULUAN}

Staphylococcus aureus adalah bakteri Gram positif berbentuk bulat dan bergerombol yang bersifat patogen serta dapat menyebabkan infeksi pada manusia. Staphylococcus aureus mengkoagulasi fibrin di tempat sekitar terjadinya infeksi dan di saluran getah bening sehingga terjadi radang dan fibrosis jaringan. Infeksi lain yang disebabkan oleh Staphylococcus aureus diantaranya pneumonia, abses paru, meningitis, endokarditis, infeksi laring, infeksi saluran urine disertai dengan pembentukan nanah dan infeksi kulit (Rostinawati, 2010).

Salah satu upaya penanganan penyakit infeksi yang disebabkan oleh bakteri Staphylococcus aureus yaitu dengan menggunakan berbagai jenis obat antibiotik. Namun, penanganan infeksi dengan menggunakan antibiotik mengalami permasalahan resistensi. Adanya resistensi bakteri terhadap antibiotik ini memicu perkembangan penelitian obat berbahan tumbuhan yang mampu meminimalisir terjadinya resistensi penggunaan antibiotik tertentu dalam mengobati penyakit yang disebabkan oleh bakteri (Budiani dan Adiguna, 2014).

Berbagai upaya telah dilakukan untuk mengatasi permasalahan resistensi bakteri oleh antibiotik secara alami dengan memanfaatkan ekstrak yang berasal dari tanaman maupun makhluk hidup lainnya yang dikenal dengan antimikroba atau antibakteri. Salah satu antimikroba yang dikenal yaitu dengan memanfaatkan kulit pisang. Limbah kulit pisang mengandung beberapa komponen zat kimia yang mampu dimanfaatkan sebagai obat di antaranya yaitu tannin, flavanoid, saponin, glikosida, terpenoid, dan alkaloid (Ighodaro, 2012).

Berdasarkan hasil penelitian yang dilakukan oleh Normayunita dkk (2015) ekstrak kulit mentah buah pisang Ambon (Musa paradisiaca var.sapientum) memiliki aktivitas antibakteri terhadap bakteri Staphylococcus aureus. Hasil penelitian juga menunjukkan bahwa kandungan tannin pada kulit pisang kepok lebih banyak terdapat pada kulit buah pisang yang belum matang dari pada kulit buah yang telah matang. Hal ini karena terjadinya peningkatan etanol, hingga 70 kali lipat, pada proses pematangan pisang menyebabkan turunnya kandungan tannin. Senyawa tannin dapat membunuh bakteri karena mempunyai daya anti bakteri (Saraswati, 2015). Sedangkan, saponin dan alkaloid mempengaruhi membran sel, 
tannin menghambat sistesis kitin di dinding sel sedangkan flavonoid menunjukan proses supresif terhadap adhesi mikroorganisme. (Dinastutie, 2015).

\section{METODE}

Metode yang digunakan dalam penelitian ini menggunakan metode kuantitatif dilakukan di Laboratorium dengan sampel penelitian yaitu ekstrak kulit Pisang Agung Semeru Varietas Lumajang. Penelitian ini dilakukan di Laboratorium Biologi FP. MIPA IKIP PGRI Jember. Pisang tersebut diperoleh dari Daerah Senduro Kabupaten Lumajang

Alat-alat yang digunakan selama penilitian, antara lain; alat penelitian berupa seperangkat alat ekstraksi, seperangkat alat Kromatografi Cair Vakum (KCV), vacuum rotary evaporator, laminar air flow, oven, inkubator gelas kimia, Erlenmeyer, cawan Petri, cawan porselin, jarum ose, pinset, bunsen, autoklaf, laminar air flow ( LAF), mikropipet, jangka sorong, corong Buchner, corong pisah, gelas ukur, tabung reaksi, dan timbangan analitik.

Simplisia penelitian ini menggunakan kulit pisang Agung Semeru (Musa pradisiaca) yang diperoleh dari pedagang pisang Agung Semeru, Kabupaten Lumajang, Provinsi Jawa Timur. Media pertumbuhan yang digunakan adalah Nutrient Agar (NA) dan garam fisiologis. Mikroba uji yang digunakan adalah Staphylococcus aureus yang diperoleh dari Laboratorium Farmasi Fakultas Farmasi Universitas Jember. Bahan-bahan yang digunakan etanol 96\%, akuades steril, alkohol $70 \%$, aluminium foil, tissue steril, kapas, kertas saring, spidol, kertas label, karet gelang, solvent Tween 80 pada berbgai konsentrasi.

Tahap awal dalam penelitian yaitu melakukan proses ekstraksi kulit pisang Agung Semeru, dimana kulit pisang tersebut dibersihkan terlebih dahulu dan di potong menjadi berukuran lebih kecil. Bahan selanjutnya dicuci di bawah air mengalir sampai bersih, ditiriskan, lalu dikeringkan dengan cara diangin-anginkan kemudian dioven selama 5 hari dengan suhu $45^{\circ} \mathrm{C}$. Sampel yang telah kering diserbukkan dengan menggunakan blender, serbuk yang dihasilkan diayak menggunakan ayakan mesh 60 hingga diperoleh serbuk simplisia yang halus dan seragam. Hasilnya dimasukkan ke dalam wadah gelas tertutup (Saraswati, 2015). 
Ekstraksi kulit pisang dilakukan dengan menggunakan teknik maserasi . Proses maserasi diawali dengan memasukkan serbuk simplisia yang akan digunakan ke dalam maserator dan dibasahi dengan pelarut etanol $96 \%$ hingga semua serbuk terbasahi. Perbandingan serbuk dan pelarut yang diganakan adalah 1:10. Maserator ditutup rapat dan dibiarkan selama 2 x 24 jam pada suhu kamar. Pengadukan dilakukan 2-3 menit menggunakan spatula. Setelah dimaserasi ( \pm 2 jam dari waktu maserasi dimulai) ekstrak disaring menggunakan kertas saring sehingga terbentuk filtrat dan ampas. Residu kembali disaring sampai $2 \mathrm{x}$ penyaringan. Filtrat terakhir dipekatkan menggunakan Rotary Evaporator pada suhu $40^{\circ} \mathrm{C}$ sehingga diperoleh ekstrak pekat etanol 96\%. Ekstrak yang diperoleh kemudian diidentifikasi secara organoleptis. Pemeriksaan organoleptis meliputi bentuk, warna, bau dan rasa (Meilina, 2015).

Tahap kedua yaitu peangujian aktivitas antibakteri ekstrak kulit pisang. Pengujian daya antibakteri ekstrak etanol kulit pisang Agung Semeru dilakukan dengan metode difusi kertas cakram. Suspensi bakteri uji diambil $0,5 \mathrm{~mL}$ dituangkan pada cawan Petri lalu dituangkan media NA $10 \mathrm{~mL}$ dengan keadaan steril, dihomogenkan, dan dibiarkan-memadat.

Ekstrak kulit pisang Agung Semeru diencerkan menggunakan air destilasi dengan konsentrasi 100, 50, 25, 12.5, 6.2, 3,1 mg/mL. Kemudian, masing-masing konsentrasi ekstrak dimasukkan dalam tabung reaksi. Sebanyak 3 buah kertas cakram dengan ukuran 14,20 mm kosong yang steril dimasukkan ke dalam masing-masing tabung reaksi dan didiamkan selama 10 menit, kemudian dengan pinset kertas cakram ditiriskan pada bagian pinggir tabung selama 10 menit. Kertas cakram yang telah dijenuhkan dengan menggunakan pinset diletakkan di atas media NA padat yang berisi mikroba uji. Sebagai kontrol negatif diletakkan pula kertas cakram yang telah dijenuhkan dalam larutan akuades dan sebagai pembanding (kontrol positif) digunakan kertas cakram dalam larutan etanol 96\%. Uji dilakukan dengan 3 kali ulangan (triplo) sehingga tap cawan berisi 3 kertas cakram. Cawan yang berisi kertas cakram tersebut kemudian diinkubasi pada suhu $37^{\circ} \mathrm{C}$ selama 18 - 24 jam. Pengamatan uji daya antibakteri dilakukan dengan mengukur diameter daerah hambat (DHP) pertumbuhan bakteri yang terbentuk di sekitar kertas cakram dengan jangka sorong. Pengukuran dilakukan dalam satuan milimeter $(\mathrm{mm})$. Uji positif ditandai dengan terbentuknya 
halo jernih (daerah penghambatan) di sekitar paper disk setelah masa inkubasi, yang menunjukkan adanya aktivitas antimikroba.

Data yang diperoleh berupa diameter zona hambat pertumbuhan bakteri Staphylococcus aureus dan selanjutnya data tersebut akan dianalisis secara statistik dengan uji non parametrik Kruskall-Wallis dan dilanjutkan dengan uji Duncan's taraf signifikansi $1 \%$.

\section{HASIL DAN PEMBAHASAN}

Hasil dari penelitian yang telah dilakukan, secara sederhana dapat dirinci dalam Tabel 1.

Tabel 1. Notasi Data DHP Staphylococcus aureus

\begin{tabular}{ccc}
\hline $\begin{array}{c}\text { Konsentrasi } \\
\text { Ekstrak (mg/mL) }\end{array}$ & $\begin{array}{c}\text { DHP Kulit Pisang } \\
\text { Matang }\end{array}$ & $\begin{array}{c}\text { DHP Kulit Pisang } \\
\text { Mentah }\end{array}$ \\
\hline $\mathbf{3 , 0 1}$ & $19.05 \pm .417^{\mathrm{a}}$ & $19.08 \pm .0623^{\mathrm{a}}$ \\
\hline $\mathbf{6 , 2 5}$ & $20.07 \pm .0849^{\mathrm{b}}$ & $20.11 \pm .1177^{\mathrm{b}}$ \\
\hline $\mathbf{1 2 , 2 5}$ & $20.11 \pm .0235^{\mathrm{b}}$ & $20.27 \pm .3184^{\mathrm{b}}$ \\
\hline $\mathbf{2 5}$ & $20.08 \pm .1178^{\mathrm{b}}$ & $20.17 \pm .1228^{\mathrm{b}}$ \\
\hline $\mathbf{5 0}$ & $21.05 \pm .1414^{\mathrm{c}}$ & $21.56 \pm .2624^{\mathrm{c}}$ \\
\hline $\mathbf{1 0 0}$ & $21.00 \pm .1649^{\mathrm{c}}$ & $21.66 \pm .2577^{\mathrm{c}}$ \\
\hline
\end{tabular}

Keterangan : a,b,c menujukkan ada perbedaan signifikan antara perlakuan dengan mengggunakan uji Duncan's pada taraf kepercayaan $99 \%$.

Pengujian aktivitas antibakteri dilakukan dengan metode difusi yang masingmasing menggunakan perlakuan dengan ekstrak kulit pisang Agung dan larutan kontrol etanol 96\%. Data yang diambil merupakan analisa terhadap daya hambat yang diberikan ekstrak kulit pisang sebagai antibiotik alami, baik yang sudah matang maupun yang masih mentah, terhadap laju penyebaran bakteri aktif. Hasil pengukuran dari beberapa perlakuan terhadap ekstrak kulit pisang selanjutnya menghasilkan rata-rata DHP kulit pisang Agung Semeru yang disajikan dalam tabel 1 dan Gambar 1. 
(p-ISSN 2527-7111; e-ISSN 2528-1615)

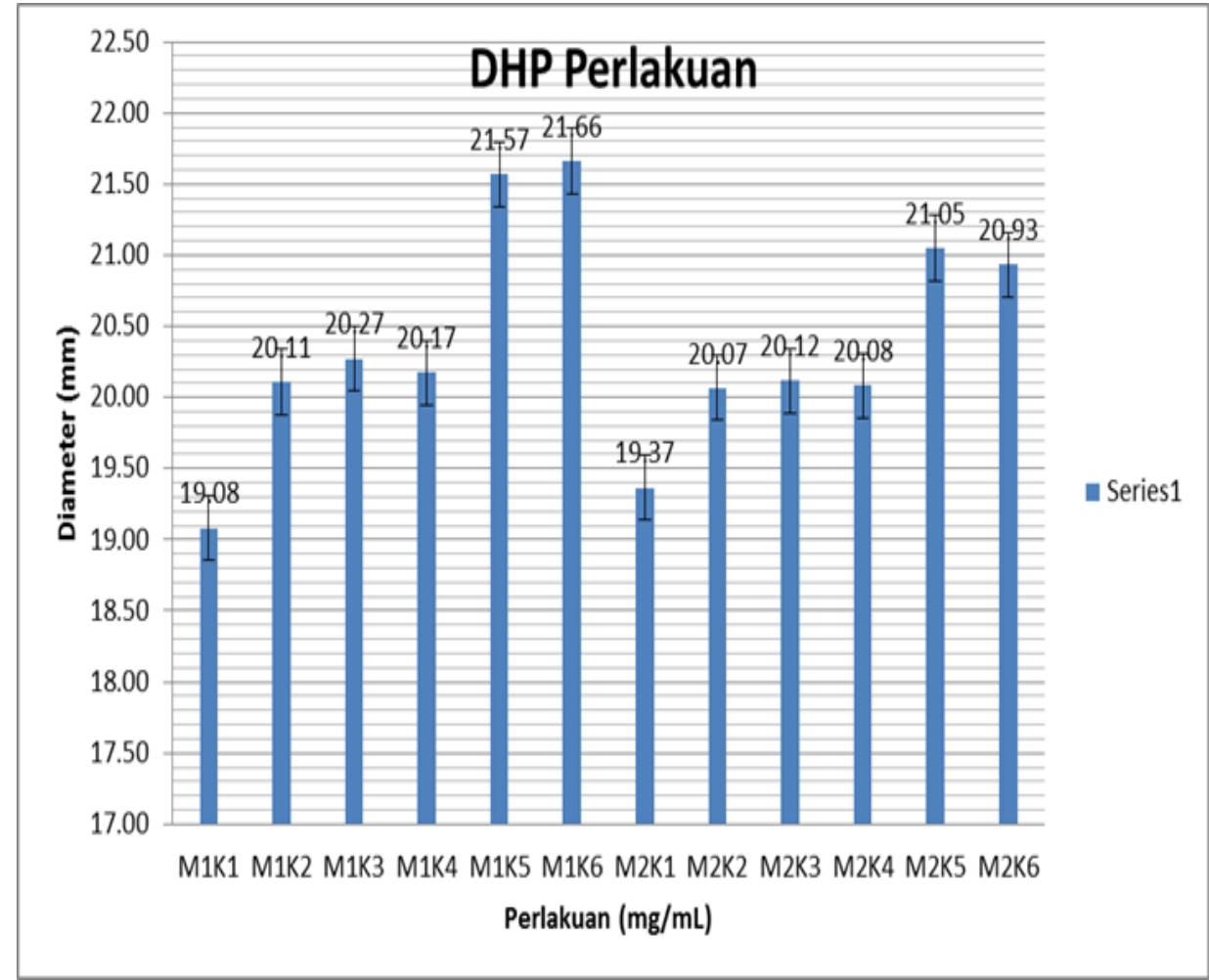

Gambar 1. Diameter Hambat Pertumbuhan (DHP) (mm) pada berbagai Perlakuan dengan berbagai konsentrasi

Berdasarkan hasil uji statistik Kruskall-wallis menunjukkan hasil Nilai Asymp. Sig. $=0,004<\alpha(0,05)$ berarti terdapat perbedaan signifikan antar kelompok perlakuan terhadap diameter hambat pertumbuhan. Sehingga berdasarkan hasil uji di atas $\mathrm{Ha}$ diterima (Ho ditolak). Hal ini memberikan arti terdapat perbedaan signifikan pengaruh tingkat kematangan dan variasi konsentrasi ekstrak kulit pisang Agung Semeru (Musa paradisiaca formatypica) terhadap daya hambat bakteri Staphylococcus aureus. Sementara itu, hasil uji lanjut menggunakan Uji Duncan menunjukkan bahwa pada konsentrasi 3,01 $\mathrm{mg} / \mathrm{mL}$ baik DHP kulit pisang matang maupun mentah hasil menunjukkan tidak memiliki perbedaan yang signifikan. Sedangkan pada konsentrasi $6,25 \mathrm{mg} / \mathrm{mL}, 12,25 \mathrm{mg} / \mathrm{mL}, 25 \mathrm{mg} / \mathrm{mL}$ baik DHP kulit pisang matang maupun mentah menunjukkan perbedaan yang signifikan dibanding dengan konsentrasi 3,01 mg/mL. Sedangkan pada konsentrasi $50 \mathrm{mg} / \mathrm{mL}$ dan $100 \mathrm{mg} / \mathrm{mL}$ baik DHP kulit pisang matang maupun mentah hasil menunjukkan tidak memiliki perbedaan yang signifikan namun menunjukkan perbedaan yang signifikan dibanding dengan konsentrasi $3,01 \mathrm{mg} / \mathrm{mL}$, $6,25 \mathrm{mg} / \mathrm{mL}, 12,25 \mathrm{mg} / \mathrm{mL}, 25 \mathrm{mg} / \mathrm{mL}$. 
Hasil uji aktivitas antibakteri terhadap bakteri Staphylococcus aureus menunjukkan bahwa ekstrak kulit buah mentah maupun matang dapat menghambat pertumbuhan bakteri Staphylococcus aureus. Hal itu dapat dilihat dari zona bening yang terbentuk di sekitar kertas cakram. Adapun hasil rata-rata diameter zona hambat terbesar pada konsentrasi $100 \mathrm{mg} / \mathrm{mL}$ pada kulit pisang matang sebesar 21,00 $\mathrm{mm}$ dan kulit pisang mentah 21,66 mm. Sementara itu, hasil rata-rata diameter zona hambat terendah pada konsentrasi 3,01 mg/mL dengan tingkat kematangan kulit pisang matang yaitu 19,01 mm dan kulit pisang mentah 19,08 mm. Berdasarkan ketentuan Suryawiria dalam Zahro (2013) ekstrak kulit pisang Agung Semeru mentah maupun matang tergolong memiliki daya hambat sangat kuat karena bernilai >20 mm dan kuat karena bernilai 10-20 mm. Hal ini menunjukkan bahwa semakin tinggi konsentrasi kandungan ektrak kulit pisang menujukkan hasil diameter hambat yang semakin besar.

Sementara itu, untuk tingkat kematangan kulit pisang menunjukkan kulit pisang mentah memiliki daya hambat yang lebih besar dibandingkan dengan kulit pisang matang. Berdasarkan penelitian Saraswati (2015) pada kulit pisang mentah memiliki kandungan tannin yang lebih besar dibandingkan kulit pisang matang.

Kemampuan ekstrak kulit pisang Agung Semeru menghambat pertumbuhan bakteri ini disebabkan karena adanya senyawa aktif yang terkandung di dalam kulit pisang (Musa paradisiaca) di antaranya yaitu tannin, flavanoid, saponin, glikosida, terpenoid, dan alkaloid. Senyawa aktif tersebut memengaruhi baik struktur dan fungsi dari bagian sel Staphylococcus aureus seperti pada dinding sel dan membran sel. Dinding sel berfungsi sebagai pelindung sel dari lingkungan dan memberi bentuk pada sel. Selain itu, dinding sel ikut berperan dalam proses kolonisasi Staphylococcus aureus. Sedangkan membran sel memiliki fungsi menjaga kestabilan dan permeabilitas membran (Ighodaro, 2012).

Unsur pertama yang terdapat dalam ekstrak kulit pisang adalah tannin, dimana tannin ini memiliki aktivitas sebagai antibakteri yang mampu menginaktifkan adhesin sel bakteri, enzim dan mengganggu transportasi protein sel (Cowan, 1994). Selain itu, senyawa tannin bersifat toksik (Akiyama et al., 2001) serta dapat mengganggu polipeptida dinding sel mikroba yang menyebabkan sel bakteri menjadi lisis dikarenakan tekanan osmosis sel (Sari dan Sari (2011). Unsur kedua yang terdapat pada kulit pisang adalah saponin. Saponin bekerja mengikat ergosterol. Dampaknya, 
terjadi peningkatan permeabilitas membran sel yang memicu terjadinya kebocoran sel, dengan keluarnya komponen penting bakteri ke luar sel mengakibatkan sel lebih mudah mati (Nuria et al., 2009 dan Cavalieri et al., 2005).

Unsur ketiga adalah alkaloid. Kerja alkaloid hampir sama dengan saponin, yaitu bekerja melubangi membran sel sehingga sel menjadi lemah. Unsur keempat adalah flavonoid. Leukosianidin merupakan jenis flavonoid yang terdapat dalam kulit pisang. Flavonoid dapat melakukan supresi adhesi pada sel host, serta flavonoid berikatan dengan protein ekstraseluler terlarut dan merusak membran sel dengan mendenaturasi ikatan protein pada sel membran sehingga sel menjadi lisis (Dinastutie dkk, 2015 dan Bobbarala, 2012). Selain itu, flavonoid mampu menginhibisi sintesis DNRA-RNA dengan cara melakukan interkalasi atau penumpukan basan asam nukleat sehingga mengganggu metabolisme energi mikroba dan biosintesis makromolekul (Cushnie dan Lamb, 2005).

\section{KESIMPULAN DAN SARAN}

Berdasarkan hasil dan pembahasan pada penelitian ini, maka dapat disimpulkan bahwa terdapat aktivitas antibakteri ekstrak kulit pisang Agung Semeru terhadap bakteri Staphylococcus aureus yang terbukti dengan terbentuknya DHP serta terdapat perbedaan aktivitas pengaruh tingkat kematangan dan variasi konsentrasi ekstrak kulit pisang Agung Semeru antar kelompok perlakuan dalam melawan bakteri Staphylococcus aureus .

Berdasarkan hasil penelitian ini, diharapkan dapat dilakukan pengujian lebih lanjut tentang perbedaan dan persentase kandungan senyawa fitokimia ekstrak kulit pisang Agung Semeru dengan tingkat kematangan yang berbeda, serta mengetahui mekanisme kerja antimikroba ekstrak kulit pisang Agung Semeru pada mikroorganisme.

\section{DAFTAR PUSTAKA}

Akiyama, H., K. Fujii., O. Yamasaki., T. Oono., dan K. Iwatsuki. 2001. Antibacterial Action of Several Tannin against Staphylococcus aureus. Journal of Antimicrobial Chemotherapy. 48: $487-491$.

Bobbarala, V. 2012. Antimicrobial Agents. Intech, Croatia. 
Budiani, L. D., Adiguna, M. S. (2014). Penatalaksanaan Pioderma Terkini. Terhadap Pertumbuhan Candida albicans Secara In Vitro. MDVI. Vol. 41 No. 2 Tahun $2014 ; 85-90$

Cavalieri, S.J., I.D. Rankin., R.J. Harbeck., R.S. Sautter., Y.S. McCarter., S.E. Sharp., J.H. Ortez., dan C.A. Spiegel. 2005. Manual of Antimicrobial Susceptibility Testing. American Society for Microbiology, USA

Cowan, M.M. 1999. Plant Products as Antimicrobial Agents. Clinical Microbiology Reviews. 12: $564-582$.

Cushnie, T.P.T., dan A.J. Lamb. 2005. Antimicrobial Activity of Flavonoids. International Journal of Antimicrobial Agents. 26: 343 - 356.

Dinastutie, R. YS Srie Poeranto. Hidayati, DYN. (2015). Uji Efektifitas Antifungal Ekstrak Kulit Pisang Kepok (Musa acuminata x balbisiana) Mentah Terhadap Pertumbuhan Candida albicans Secara In Vitro. Majalah Kesehatan FKUB. Volume 2, Nomer 3

Ighodaro, O.M. (2012). Evaluation study on Nigerian species of Musa paradisiaca Peels: Phytochemical screening, Proximate analysis, Mineral Composition and Antimicrobial Activities.

http://www.sciencepub.net/researcher. Diakses tanggal 3 Maret 2017

Normayunita, S. Anam, S. Khumaidi, A. (2015). Aktivitas Antibakteri Fraksi Ekstrak Kulit Buah Mentah Pisang Ambon (Musa paradisiaca var.sapientum) Terhadap Staphylococcus aureus. Online Jurnal of Natural Science. Vol. 4 No. 3. Halaman 300-309

Nuria, M.C., A. Faizatun., dan Sumantri. 2009. Uji Antibakteri Ekstrak Etanol Daun Jarak Pagar ( Jatropha cuircas L) terhadap Bakteri Staphylococcus aureus ATCC 25923, Escherichia coli ATCC 25922, dan Salmonella typhi ATCC 1408. Jurnal Ilmu - ilmu Pertanian. 5: 26 - 37.

Rostinawati, T. (2010). Aktivitas Antimikroba Ekstrak Herba Tespong (Oenanthe Javavica D.C) Terhadap Eschericia coli, Staphylococcus aureus dan Candida albicans. Universitas Padjadjaran Jatinangor

Saraswati, F. N. (2015). Uji Aktivitas Antimikroba Ekstrak Etanol 96\% Limbah Kulit Pisang Kepok Kuning ( Musa Balbasiana ) Terhadap Bakteri Penyebab Jerawat 
(Staphylococcus epidermidis, Staphylococcus aureus, Propionibacterium acne). Skripsi. UIN Syarif Hidayatullah Jakarta

Sari, F.P., dan S. M. Sari. 2011. Ekstraksi Zat Aktif Antimikroba dari Tanaman Yodium (Jatropha multifida Linn) sebgai Bahan Baku Alternatif Antibiotik Alami. Fakultas Teknik Universitas Diponegoro, Semarang.

Zahro, L.dan R.Agustini,. (2013). Uji Efektivitas Antibakteri Ekstrak Kasar Saponin Jamur Tiram Putih (Pleurotus ostreatus) Terhadap Staphylococcus aureus dan Escherichia coli. UNESA Journal of Chemistry. Vol.2 No.3 